\title{
Non-Coding RNAs in Pediatric Airway Diseases
}

\author{
Beata Narożna, Wojciech Langwiński and Aleksandra Szczepankiewicz * \\ Laboratory of Molecular and Cell Biology, Department of Pediatric Pulmonology, \\ Allergy and Clinical Immunology, Poznan University of Medical Sciences, 60-512 Poznan, Poland; \\ b.narozna@gmail.com (B.N.); wlangwinski654@gmail.com (W.L.) \\ * Correspondence: alszczep@ump.edu.pl; Tel.: +48-618-547-643
}

Received: 31 October 2017; Accepted: 21 November 2017; Published: 27 November 2017

\begin{abstract}
Non-coding RNAs (ncRNAs) are involved in the regulation of numerous biological processes and pathways and therefore have been extensively studied in human diseases. Previous reports have shown that non-coding RNAs play a crucial role in the pathogenesis and aberrant regulation of respiratory diseases. The altered expression of microRNAs (miRNAs) and long non-coding RNAs in blood and also locally in sputum or exhaled breath condensate influences lung function, immune response, and disease phenotype and may be used for the development of biomarkers specific for airway disease. In this review, we provide an overview of the recent works studying the non-coding RNAs in airway diseases, with a particular focus on chronic respiratory diseases of childhood. We have chosen the most common chronic respiratory condition-asthma-and the most severe, chronic disease of the airways—cystic fibrosis. Study of the altered expression of non-coding RNAs in these diseases may be key to better understanding their pathogenesis and improving diagnosis, while also holding promise for the development of therapeutic strategies using the regulatory potential of non-coding RNAs.
\end{abstract}

Keywords: miRNA; long non-coding RNA; asthma; cystic fibrosis; viral infection; biomarkers

\section{Introduction}

Non-coding RNAs (ncRNAs) are master regulators of gene expression that influence numerous biological pathways including proliferation, differentiation, and apoptosis, as well as immune response (innate and adaptive immunity, differentiation of $\mathrm{T}$ and $\mathrm{B}$ cells, inflammation, and tissue repair and remodeling (reviewed by [1])). Non-coding RNAs are grouped into housekeeping RNAs and regulatory RNAs. Housekeeping RNAs include those involved in ribosomal machinery, i.e. rRNAs, transfer RNAs (tRNAs), small nuclear RNAs (snRNAs) and small nucleolar RNAs (snoRNAs), whereas regulatory RNAs include short non-coding RNAs (less than 200 nucleotides) and long non-coding RNAs (longer than 200 nucleotides) [2,3]. The most commonly RNAs studied in respiratory diseases are short ncRNAs (mainly microRNAs, but recently also piwi-interacting RNAs (piRNAs) and long ncRNAs.

MicroRNAs (miRNAs) are small non-coding RNAs (18-25 nucleotides long) that regulate expression of target genes by inhibiting their translation via RNA interference [4]. They are synthesized as precursors in the nucleus, where they undergo maturation with several enzymatic reactions and are translocated to the cytoplasm where they exert their biological function in a protein complex. It has been predicted that, in humans, about $60 \%$ of mRNAs are targets for miRNA [5] and one miRNA may target more than 100 mRNAs [6]. Another group of small RNAs are piRNAs that play an important role in germline cells. They are involved mainly in transposon silencing and epigenetic DNA and histone modification in germinal cells and early embryos [7]. Recently, piRNAs have also been found in differentiated cells [8]. 
Long non-coding RNAs are heterogeneous group of non-coding RNAs with regard to origin and mechanism of action/function. Another interesting feature is that they may be expressed in both sense and antisense orientation relative to protein-coding genes [9]. Studies demonstrated that they are regulators of different cellular processes including chromatin structure changes, transcription and post-transcriptional processing, and intracellular trafficking [10]. Although their role in diseases has not yet been well characterized, it is known that they are involved in cancer development for example [11,12].

The most widely studied non-coding RNAs in airway diseases are miRNAs, but a few studies have also analyzed the role of other types (such as lncRNAs, piRNAs). The miRNAs were first studied as potential biomarkers in lung cancer (as reviewed by [13]). It was found that the differences in miRNAs with respect to normal and cancer lung tissue may be related to diagnosis and prognosis of the disease, while also offering novel therapeutic targets for lung cancer therapy [14]. In the last decade, dynamic progress has been made in discovering the role of ncRNAs in the pathogenesis and diagnosis of airway diseases.

The aim of this review is to provide an overview of the most current knowledge and to summarize existing data on ncRNAs as the causal factors involved in the pathogenesis of chronic airway diseases, as well as biomarkers of disease state. This review will focus on the two most common chronic childhood diseases of the airways, which have different genetics backgrounds: polygenic asthma, and monogenic cystic fibrosis, with particular emphasis on the central role of airway epithelium in the pathogenesis of these diseases and responses to environmental stimuli.

\section{NcRNA Studies in Asthma}

The development of microarrays and new-generation sequencing techniques in the past few decades has created the possibility of determining the expression and sequencing of many non-coding RNAs in a single reaction. This progress has significantly increased our knowledge about the role of non-coding RNAs in the pathogenesis of allergic asthma [15-17]. Numerous papers have highlighted the potential contribution of non-coding RNAs in the pathogenesis of allergic asthma, and miRNAs seem to be a focus in these studies. A summary of studies of ncRNA in asthma is shown in Table 1.

Table 1. Non-coding RNAs (NcRNAs) in clinical and animal models of asthma.

\begin{tabular}{|c|c|c|c|c|c|c|}
\hline Class of ncRNA & Regulation & Tissue/Cell Type & Species & Condition/Treatment & Validated Target Gene & Ref. \\
\hline \multirow{7}{*}{$\operatorname{miR}-221$} & \multirow{2}{*}{$\uparrow$} & Peripheral blood & Human & Asthma & \multirow{2}{*}{ Spred-2 } & \multirow{2}{*}{ [18] } \\
\hline & & Lungs & Mouse & Asthma model & & \\
\hline & \multirow{2}{*}{$\uparrow$} & Lungs & Mouse & Asthma model & \multirow{2}{*}{ PTEN } & \multirow{2}{*}{ [19] } \\
\hline & & P815 mast cells & Mouse & Asthma model & & \\
\hline & $\downarrow$ & Eosinophils (BALF) & Mouse & Anti-sense miR-221 & - & [20] \\
\hline & $\uparrow$ & BMMCs & Mouse & miR-221 overexpression & $C d k n 1 b, K i t, I l 2 R a$ & [21] \\
\hline & $\uparrow$ & ASM & Human & Asthma & $p 27^{k i p 1}, p 21^{\text {WAF1 }}$ & [22] \\
\hline \multirow{3}{*}{ let-7 } & $\downarrow$ & $\mathrm{EBC}$ & Human & Asthma & - & [23] \\
\hline & $\downarrow$ & BALF & Human & Asthma & - & [24] \\
\hline & $\downarrow$ & Nasal biopsies & Human & Asthma & - & [25] \\
\hline \multirow{5}{*}{ miR-21 } & $\uparrow$ & Serum & Human & Asthma & - & [26] \\
\hline & $\uparrow$ & Lungs & Mouse & $\begin{array}{l}\text { OVA, Aspergillus } \\
\text { fumigatus, IL-13 }\end{array}$ & $I L-12 p 35$ & [27] \\
\hline & $\downarrow$ & Lungs & Mouse & miR-21 knock-out & - & [28] \\
\hline & $\uparrow$ & BECs & Human & Asthma & - & {$[29]$} \\
\hline & $\downarrow$ & EBC & Human & Asthma & - & [23] \\
\hline \multirow{4}{*}{ miR-126 } & $\uparrow$ & Lungs & Mouse & OVA sensitization & - & {$[30]$} \\
\hline & $\uparrow$ & BECs & Human & Asthma & - & [29] \\
\hline & $\downarrow$ & Lungs & Mouse & $\begin{array}{l}\text { OVA sensitization } \\
\text { (miR-126 inhibitor) }\end{array}$ & - & {$[30,31]$} \\
\hline & $\downarrow$ & Nasal biopsies & Human & Asthma & - & [25] \\
\hline
\end{tabular}


Table 1. Cont

\begin{tabular}{|c|c|c|c|c|c|c|}
\hline Class of ncRNA & Regulation & Tissue/Cell Type & Species & Condition/Treatment & Validated Target Gene & Ref. \\
\hline \multirow[t]{2}{*}{ miR-146 } & $\uparrow$ & THP- 1 cells & Human & $\begin{array}{c}\text { LPS and } \\
\text { pro-inflammatory } \\
\text { cytokines induction }\end{array}$ & IRAK1, TRAF6 & [32] \\
\hline & $\downarrow$ & CD4+ and CD8+ cells & Human & Asthma & - & [33] \\
\hline miR-192 & $\downarrow$ & Peripheral blood & Human & Asthma & - & [34] \\
\hline miR-485-3p & $\uparrow$ & Whole lung & Mouse & Asthma model & Spred-2 & {$[18,20]$} \\
\hline $\begin{array}{c}\text { miR-223-3p, } \\
\text { miR-629-3p, } \\
\text { miR-142-3p, } \\
\text { miR-338, miR-145 }\end{array}$ & $\uparrow$ & Sputum & Human & $\begin{array}{l}\text { Mild-to-moderate } \\
\text { asthma }\end{array}$ & - & {$[35,36]$} \\
\hline \multirow{2}{*}{ miR-155 } & $\downarrow$ & Sputum & Human & Asthma & - & [37] \\
\hline & $\downarrow$ & EBC & Human & Asthma & - & [23] \\
\hline miR-19a & $\uparrow$ & HBEpC & Human & Asthma & TGF- $\beta R 2$ & [40] \\
\hline miR-200 & $\downarrow$ & BALF & Human & Asthma & - & [24] \\
\hline $\begin{array}{c}\text { miR-1248, } \\
\text { miR-328, miR-133 }\end{array}$ & $\downarrow$ & $\mathrm{EBC}$ & Human & Asthma & - & [23] \\
\hline $\mathrm{miR}-203$ & $\downarrow$ & HBEpC & Human & Asthma & & [41] \\
\hline miR-449 & $\downarrow$ & HAECs & Human & AntagomiR-449a/b & DLL1, NOTCH1 & [42] \\
\hline \multirow{2}{*}{ miR-18a } & $\downarrow$ & BECs & Human & Asthma & - & {$[38]$} \\
\hline & $\downarrow$ & Nasal biopsies & Human & Asthma & - & {$[25]$} \\
\hline miR-22 & $\downarrow$ & Lungs & Mouse & OVA-sensitization & Creb1 & [43] \\
\hline piR-30840 & $\uparrow$ & CD4+ cells & Human & Asthma & $I L-4$ & [8] \\
\hline $\begin{array}{c}\text { LINC00472, } \\
\text { RP5-1158E12.3, } \\
\text { FKBP1A-SDCBP2 }\end{array}$ & & ASMCs & Human & $\begin{array}{c}\text { Non-severe and severe } \\
\text { asthma }\end{array}$ & - & \multirow[b]{2}{*}[44]{} \\
\hline PVT1 & $\uparrow$ & ASM & Human & $\begin{array}{l}\text { Upregulated in patients } \\
\text { with severe asthma as } \\
\text { compared to patients } \\
\text { with non-severe asthma }\end{array}$ & - & \\
\hline BCYRN1 & $\uparrow$ & Lungs & Rat & Asthma model & TRPC1 & [45] \\
\hline
\end{tabular}

BALF: bronchoalveolar lavage fluid; LPS: lipopolysaccharide; OVA: ovalbumin; BMMCs: bone marrow-derived mast cells; ASM: airway smooth muscle, BECs - bronchial epithelial cells, HAEs - human airway epithelial cells, EBC - exhaled breath condensate, HBEpC - human bronchial epithelial cells.

Several studies on miRNA expression profiling report the importance of miRNAs in the regulation of airway inflammation in asthma. In one of the first studies, Liu et. al. demonstrated that 83 miRNA genes were differentially expressed (36 up-regulated and 47 down-regulated) in the blood of asthmatic children as compared to control subjects [18]. Using a murine model of asthma, the authors demonstrated that miR-221 exhibited increased expression in the lungs of sensitized animals, similar to that observed in the blood of asthmatic children [18]. MiR-221 in silico was predicted to target the Spred-2 gene, encoding Sprouty-related protein with EVH1 domain-2, that was downregulated in the lungs of sensitized mice. Elevated expression of miR-221, that correlated with increased eosinophil counts in bronchoalveolar lavage fluid (BALF), was also reported in the lungs of allergic animals [19]. Moreover, inhibition of miR-221 with a synthetic inhibitor significantly reduced eosinophil numbers in BALF from asthmatic mice [20], whereas its overexpression stimulated 
P815 mast cells to increase synthesis and secretion of IL-4, crucial in Th2 polarization during allergic inflammation [19]. Apart from cytokine production, miR-221 overexpression also enhanced migration, adhesion, and antigen-induced mast cell degranulation in mouse bone marrow-derived mast cells (BMMCs) [21]. This miRNA was also suggested to be involved in airway smooth muscle proliferation, leading to thickening of the bronchial wall, airflow limitation, and dyspnea [22].

A recent study on miRNA profiling in childhood asthma showed that several miRNA genes, including let-7e, miR-98, and miR-497 demonstrated an over two-fold up-regulation in moderate-to-severe asthma as compared to the control group [46]. Moreover, in the same study the expression of HS_101, HS_206, miR-208, miR-518f, and miR-606 were increased in patients with allergic asthma as compared to non-allergic subjects. A previous functional study of the let-7 family found that let-7 inhibition suppressed production of allergic cytokines, suggesting its pro-inflammatory function.

Another miRNA widely studied in bronchial asthma is miR-21, which showed elevated levels in the serum of asthmatic patients and was suggested as a potential biomarker for allergic asthma [26]. Lu et al., using transgenic mice with IL-13 overexpression, found 21 miRNAs differentially expressed in animals with induced inflammation as compared to transgenic mice that did not undergo induced allergic inflammation [27]. All these miRNAs were associated with the IL-13 pathway, crucial during Th2 polarization. Of these, miR-21 demonstrated the highest expression in sensitized mice when compared to control animals. The same miRNA also showed increased expression in mice sensitized to ovalbumin (OVA) or Aspergillus fumigatus, suggesting its essential and universal role in the allergic sensitization, regardless of the allergen [27]. Further studies, performed by the same authors, confirmed that knock-out of the miR-21 gene significantly reduced Th2-dependent inflammation in mice exposed to OVA [28]. Both miR-21 and miR-126 were overexpressed in OVA-sensitized mice [30], as well as in bronchial epithelial cells from asthmatic patients [29]. MiR-126 inhibition significantly decreased Th2-dependent response, namely allergen-induced hyper-responsiveness and eosinophil recruitment in sensitized animals [30,31].

Frequently studied in atopic asthma were also miR-146a and miR-146b, considered as transcription factor NF-kB-dependent, negative regulators of inflammatory genes [47]. It was shown that lipopolysaccharides (LPS) and pro-inflammatory cytokines (IL-1 $\beta$ ) stimulated miR-146 synthesis, whereas genes involved in the Toll-like receptors pathway, TRAF6 and IRAK1, were suggested as miR-146 target genes [32]. Studies performed on clinical samples confirmed elevated expression of miR-146a in the plasma of asthmatic children. Its expression may be also affected by variation in the miR-146 gene sequence. It was demonstrated by Jazdzewski et al. that a polymorphism (rs2910164) in pre-miR-146a significantly decreased the level of functional miRNA-146a [48] and this variant was associated with asthma in the Mexican female population [49].

Another candidate miRNA in atopic asthma is miR-499. Toraih et. al. [50] demonstrated that a polymorphism (rs3746444), resulting in $A>G$ substitution in the seed region of this miRNA gene, was associated with asthma risk in the population of Egyptian children and adults. The same polymorphism showed a significant association with spirometry results (increased forced expiratory volume in $1 \mathrm{~s}, \mathrm{FEV}_{1}$ ) in a population of Korean patients with AG/GG genotype in comparison to patients with AA genotype [51]. Moreover, other miRNA gene polymorphisms (rs11614913 in miR-196a2 and rs2910164 in miR-146a) were associated with eosinophilic phenotype of asthma and increased bronchial hyper-responsiveness.

MiRNAs from the 146 family (miR-146a and miR-146b) were downregulated in circulating CD4+ and CD8+ T cells from severely asthmatic patients, but not in those with non-severe asthma [33]. It was shown that miR-146a and miR-146b negatively regulate the immune response [47] and their reduced expression may activate T-cells. In addition to studies of $\mathrm{T}$ cells, a number of reports have examined peripheral blood mononuclear cells and have shown miR-192 downregulation in mild asthmatics [34] and miR-211 and miR-485-3p upregulation in pediatric patients with asthma $[18,20]$. Another study of miR-146b and also 21 other miRNAs reported an association with spirometry results in asthmatic children [52]. Moreover, the authors demonstrated that 4 and 8 miRNA genes correlated with forced 
expiratory volume in $1 \mathrm{~s}\left(\mathrm{FEV}_{1}\right)$ and forced vital capacity (FVC), respectively, suggesting the potential role of circulating miRNAs as biomarkers for lung function in asthma.

Although peripheral blood is the most commonly studied material, it does not reflect specific changes in the airways upon inflammation. Less frequently used, but more specific for local inflammation, are sputum, BALF, and exhaled breath condensate. MiRNA profiling in BALF extracellular vesicles (EVs) [53] revealed 85 miRNAs that were differentially expressed between control mice and mice with allergic inflammation, induced by exposure to house dust mite (HDM). Moreover, 54 of these altered miRNAs were common between both EVs and the lung tissue from allergic animals. Furthermore, HDM sensitization significantly increased extracellular vesicle secretion, suggesting their potential role in transcellular communication upon allergen sensitization. Another miRNA study on exosomes from the BALF of asthmatic patients demonstrated 24 differentially expressed miRNAs, suggesting let-7 and miR-200 families as potential asthma biomarkers [24].

Studies analyzing miRNA expression profile in the sputum from mild-to-moderate asthmatic patients demonstrated elevated expression of miR-223-3p, miR-629-3p, miR-142-3p, miR-338, and miR-145 [35,36]. Furthermore, a strong association was found between increased expression of three miRNAs (miR-223-3p, miR-629-3p, and miR-142-3p), and severe asthma; these miRNAs were also negatively associated with spirometry results [36]. Another study performed in sputum of asthmatic patients demonstrated a significant downregulation of miR-155 as compared to controls [37]. Moreover, the expression of this miRNA was the lowest in the asthmatic patients during the allergic season, when compared to allergic patients after pollen season. Interestingly, mice with miR-155 gene knock-out demonstrated lung remodeling and elevated leukocyte number in BALF and after sensitization, these transgenic mice demonstrated significantly decreased IL-2 and IFN $\gamma$ expression in comparison to sensitized mice without knock-out, suggesting a protective anti-inflammatory function of miR-155 [39].

MiRNA expression was also analyzed in exhaled breath condensates from asthmatic patients and control subjects, showing decreased expression of several miRNAs in asthma (miR-1248, let-7a, miR-155, miR-21, miR-328, and miR-133a) [23].

Bronchial epithelial brushings from subjects with asthma and healthy controls were analyzed on microarrays, revealing an altered profile of miRNA expression [38,41,54], with the exception of Williams et al., who studied a mild asthma phenotype [55]. Jardim et al. discovered 66 differentially expressed miRNAs on comparing healthy and asthmatic donors [41]. Further validation of their findings was concentrated on miR-203, implicated in immunological disorders. Target predictions have identified $A Q P 4$, a gene encoding a member of the aquaporin family, as a possible target for miR-203. $A Q P 4$ transcript expression was significantly higher in asthmatic donors.

In a study by Solberg et al. the authors found significant differences in the expression of 217 miRNA genes when comparing steroid-naive asthmatic patients and healthy controls, while 200 miRNA genes differed between steroid-using asthmatics as compared to steroid-naïve patients; 170 of these miRNAs were shared between these two asthmatic groups [54]. Treatment with inhaled corticosteroids (ICS) for steroid-naive subjects has shown to normalize the changes in expression of several miRNAs. Interestingly, the members of the miR-34/449 family were highly repressed in asthma; in vivo experiments have shown that their expression levels are also decreased after IL-13 treatment. MiR-449, whose expression is increased during the proliferation and differentiation of airway ciliated cells, has been confirmed to target NOTCH1 mRNA. As a result, ciliated cells are reduced in number, whereas the number of mucous cells increases, implying an miR-449 contribution to altered epithelial differentiation observed in asthma [42,54]. MicroRNA profiling by Martinez-Nunez et al. detected 33 up-regulated and 91 down-regulated microRNAs when comparing bronchial epithelium obtained from asthmatics and healthy donors [38]. Several microRNAs (miR-18a, miR-27a, miR-128 and miR-155) were down-regulated in asthmatic bronchial epithelium, and biological pathway analysis suggested that they may affect TGF- $\beta$, IL-6, IL-8, and IFN signaling. Further study of gene targets has implicated that the microRNA network may exert its effect through a combination of targets 
(transcription factors NFATs, NFKB, CREB1, CEBPB, CEBPA, GR, RELA, signaling transducers MAPK and $\mathrm{mTOR}$ ), as opposed to the regulation of only a single target [38].

Another miRNA profiling study found that only miR-19a differentiated severe asthma from mild asthma patients and healthy controls, as no significant differences in expression were found for mild asthmatics [40]. Further experiments confirmed that up-regulation of miR-19a increased proliferation rates by inhibiting TGF-beta receptor 2. Over-expression of this miRNA also resulted in reduced levels of the phosphorylated activated form of SMAD3.

Selected miRNAs were also analyzed in nasal biopsies from asthmatic patients and healthy donors, revealing differential expression of 10 miRNAs (miR-18a, miR-126, let-7e, miR-155, miR-224 were down-regulated, while miR-498, miR-197, miR-874, miR-143, miR-886-3p were up-regulated) [25]. Analysis of patients with asthma and allergic rhinitis showed further alterations in expression for six miRNAs: miR-224, miR-498, miR-187, miR-874, miR-143, miR-886-3p as compared to the control subjects.

Another approach to microRNA profiling was used by Bartel et al. who first performed microarrays on mice with induced airway inflammation, followed by target prediction for the top 100 dysregulated miRNA genes, and enabled identification of Creb1, confirmed to be regulated by miR-17, miR-144, and miR-22 via luciferase reporter assay [43]. Further validation was performed after allergen challenge in mice and in primary human bronchial epithelial (NHBE) cells after IL-13 treatment, confirming down-regulation of the CREB1/CRTC pathway.

Another group of small non-coding RNAs recently found in human CD4+ T cells are piwi-interacting RNAs (piRNAs). One of them, piR-30840, was shown to downregulate IL-4 expression and Th2 cell development, thus inhibiting allergic inflammation and allergic asthma [8]. Interestingly, piR-30840 inhibition with an antisense inhibitor resulted in significant upregulation of IL-4 in Th2 cells, suggesting its potential role as an anti-inflammatory agent.

In addition to miRNAs, long non-coding RNAs also play a crucial role in the immune reactions, including allergic asthma [44]. Microarray study has revealed 21 and 19 differentially expressed lncRNAs in airway smooth muscle cells from patients with non-severe and severe asthma, respectively, as compared to healthy individuals. Moreover, LINC00472, RP5-1158E12.3 and FKBP1A-SDCBP2 demonstrated similar expression patterns in patients with non-severe and severe asthma as compared to the control group. Interestingly, PVT1 was significantly increased in patients with severe asthma and decreased in patients with non-severe asthma. PVT1 was also involved in proliferation and IL-6 release in airway smooth muscle (ASM) from patients with severe asthma. Another study analyzing long ncRNAs found that brain cytoplasmic RNA 1 (BCYRN1) was dysregulated in airway smooth muscle (ASM) cells, which are crucial during bronchial remodeling in asthma [45]. Using a rat model of asthma, the authors demonstrated increased expression of BCYRN1 in sensitized rats as compared to control animals. This increase correlated with increased transient receptor potential channel 1 gene expression (TRPC1), responsible for enhanced transmembrane $\mathrm{Ca}^{2+}$ transport and ASM cell proliferation in asthmatic patients, contributing to bronchoconstriction and dyspnea. Furthermore, it was found that $B C Y R N 1$ induced TRPC1 expression [56] and overexpression of BCYRN1 resulted in increased viability, proliferation, and migration rate of ASM from sensitized animal lungs, whereas BCYRN1 inhibition significantly attenuated these processes [45]. Another study showed reduced expression of MEG3, a lncRNA, in the circulating CD8+ T cells in severe asthma, as well as the differential expression of an additional 18 lncRNAs [33].

All of these findings indicate that non-coding RNAs may be involved in the pathogenesis of asthma, not only in the airways regulating local inflammation and airway remodeling, but also on the periphery, thus mediating systemic inflammation in asthma. They also show potential as future biomarkers of this disease. 


\section{NcRNA Studies in Cystic Fibrosis}

Cystic fibrosis (CF) is a genetic disorder caused by mutations in the CFTR gene and is the most common chronic, genetically determined, lethal disease. The gene encodes a transmembrane channel that regulates ion exchange between cells and extracellular space. The mutations in the CFTR gene result in aberrant protein translation, folding, or trafficking that lead to aberrant regulation of ion exchange and mucus accumulation that are the cause of recurrent airway inflammation and infections decreasing the lung function and shortening the lifespan [57].

Non-coding RNA studies in CF have primarily focused on their role in regulating CFTR function, as well as controlling immune responses in CF airways. Several analyses provided evidence that miRNA genes (miR-101, miR-145, miR-223, miR-384, miR-494, miR-509-3p, and miR-1246) regulate CFTR expression, as well as anion transport, particularly in patients with F508del mutation [58-62]. Increased expression of miR-145, miR-223, and miR-494 was found in bronchial brushings from CF patients as compared to non-CF brushings $[61,62]$ and demonstrated the complexity in post-transcriptional regulation of CFTR. Megiorni et al. found that increased levels of miR-101 and miR-494 repress CTFR expression in vitro [59], whereas miR-138 was found to repress SIN3A, leading to increased CFTR levels [63]. The latter study suggested that miR-138 may improve biosynthesis of CFTR-DF508 and restore anion transport to cystic fibrosis airway epithelium.

Interestingly, genetic variants located in the target gene region that binds miRNA might also alter the recognition site for miRNA, affecting the binding to the targeted transcript. This has been observed by Amato et al. who found that the CFTR polymorphism (rs10234329) enhances the affinity for miR-509-3p, a potential CFTR transcript modulator [64]. Moreover, miR-16 was discovered to restore the deltaF508 CFTR protein function by regulating the cAMP-activated chloride conductance and by reducing the IL-8 expression [65].

An example of miRNA polymorphisms influencing their maturation was reported by Endale Ahanda [66]. They found three polymorphisms in miR-99b/let-7e/hsa-miR-125a gene cluster derived from the same precursor that influence maturation of their primary transcripts and deltaF508-CFTR mutation can induce an upregulation of miR-99b and miR-125a gene expression, indicating that these miRNAs are important in CF pathogenesis.

Confirmation that ncRNAs may be important in CF severity also may be found in the fact that miR-9 was found to downregulate anoctamin 1 (ANO1) by direct binding to the target sequence in this gene [67]. Anoctamin 1 (ANO1) is a Ca2+ activated $\mathrm{Cl}$ - channel in airway epithelium that was found downregulated in CF patients, contributing to disease severity. The use of a microRNA target site blocker for miR-9 increased ANO1 activity and compensated the deficient transmembrane conductance in CF [67].

The inflammatory responses in $\mathrm{CF}$, particularly during pulmonary exacerbations in both innate and adaptive immune responses, may be also controlled by ncRNAs that influence gene expression in inflammatory conditions [68]. Numerous miRNAs were found to be dysregulated in CF lungs (reviewed by [69]). In a study by Oglesby et al. [70], the authors observed decreased miR-17 expression in CF bronchial cells that correlated with enhanced inflammatory cytokine (IL-8) production. Another miRNA that increased expression-stimulated release of inflammatory cytokines in airway epithelial CF cells was miR-155 [71]. The authors discovered high expression of miR-155 in CF airway epithelial cells, both in vitro and in vivo, that subsequently indirectly activated PI3K/Akt signaling and contributed to intrinsic MAPK activation and IL-8 stabilization [71]. In another study, an increased expression of miR-145 was negatively correlated with target gene expression of SMAD3 in nasal epithelium from $C F$ patients, thus suggesting it may influence regulation of the inflammatory pathway of TGF- $\beta 1$ and explain the abnormalities in SMAD3-mediated TGF- $\beta 1$ signaling observed in CF [58].

A study on miRNA profiling in bronchial brushings from CF patients and healthy controls showed numerous dysregulated miRNA genes (56 down-regulated and 36 up-regulated) [72]. Out of these, miR-126 was further studied and its down-regulation correlated with upregulation of its direct target, TOM1, that encodes the protein involved in the endosomal trafficking of ubiquinated proteins. Another miRNA significantly elevated in CF brushings, miR-221, was found to down-regulate ATF6, along 
with miR-145 and miR-494 [70]. Interleukin-8 mRNA expression was measured in bronchoalveolar lavage fluid and bronchial brushings from CF patients and non-CF controls, showing significantly higher levels in CF [70]. MiR-17 was found to be more effective modulator of IL-8 expression than let- $7 \mathrm{~b}$, and its over-expression caused decreased production of interleukin-8.

The studies on miRNA profile and their use as potential biomarkers of CF are limited. So far, there has been one study suggesting that the miRNA expression profile may play a role in airway disease in CF [73]. The authors found that decreased miR-31 in the CF airways influences cathepsin $\mathrm{S}$ (CTSS) expression in epithelial cells via a transcription factor (IRF-1) responsible for host defense cellular response in CF airway epithelial cells. The authors also observed that treating CF bronchial epithelial cells with a miR-31 mimic decreased IRF-1 protein levels as well as catepsin S expression and secretion, thus reducing lung inflammation [73].

Apart from miRNAs, other types of non-coding RNAs have also been studied in CF. Microarray profiling study revealed more than 1000 differentially expressed lncRNAs between bronchial brushings of CF patients and non-CF controls, including lncRNA XIST, HOTAIR, MALAT and TLR8-AS1 [69]. Additional analysis of protein coding transcripts revealed that lncRNAs and mRNAs are linked, since many are divergently transcribed at the promoters of protein coding genes. The authors also found that Toll-like receptor 8 (TLR8) mRNA was highly expressed in CF samples, whereas the level of its antisense lncRNA transcript TLR8-AS1 was low, suggesting it may play a role in viral exacerbations in CF [69].

Moreover, a recent study found that CFTR is regulated transcriptionally by a novel long non-coding RNA (lncRNA), BGas, that originates from intron 11 of CFTR gene, but is expressed in the antisense orientation relative to the protein coding sense strand [74]. The authors found that BGas affects CFTR transcription via alterations of local chromatin and DNA structure and its suppression restores CFTR expression and ion channel function. This may offer a novel therapeutic approach and BGas may be a target for activating expression of CFTR. The results of ncRNAs in clinical studies and in vitro model of cystic fibrosis are summarized in Table 2.

Table 2. NcRNAs in cystic fibrosis.

\begin{tabular}{|c|c|c|c|c|}
\hline Class of ncRNA & Regulation & Tissue/Cell Type & Validated Target Genes & Ref. \\
\hline $\begin{array}{l}\text { miR-145, miR-384, } \\
\text { miR-494, miR-1246 }\end{array}$ & - & Caco-2 cell line & CFTR & {$[60,62]$} \\
\hline miR-101, miR-494 & $\uparrow($ mimic $)$ & HEK293 & CFTR repressed & [59] \\
\hline miR-145, miR-223, miR-494 & $\uparrow$ & bronchial brushings & CFTR & [61] \\
\hline miR-509-3p, miR-494 & $\uparrow$ & primary airway epithelial cells, Calu3 & CFTR decreased & {$[62]$} \\
\hline $\operatorname{miR}-138$ & $\uparrow($ mimic) & $\begin{array}{c}\text { primary airway epithelial cells, Calu-3, } \\
\text { HEK293T, HeLa, CFBE }\end{array}$ & $\begin{array}{l}\text { CFTR increased } \\
\text { SIN3A repressed, }\end{array}$ & [63] \\
\hline miR-16 & $\uparrow($ mimic $)$ & $\begin{array}{l}\text { IB3-1 CF lung epithelial cells, } \\
\text { CFPAC-1 cells }\end{array}$ & CFTR increased & [65] \\
\hline miR-9 & $\uparrow$ & CFBE41o-, 16HBE14o- & ANO1 & {$[67]$} \\
\hline miR-17 & $\downarrow$ & bronchial cells & Enhanced IL-8 & {$[70]$} \\
\hline miR-155 & $\uparrow$ & lung epithelial cells & SHIP1 reduced & [71] \\
\hline miR-145 & $\uparrow$ & nasal epithelium & SMAD3 & [58] \\
\hline miR-126 & $\downarrow$ & bronchial brushings & TOM1 & [72] \\
\hline miR-221, miR-145, miR-494 & $\uparrow$ & $\begin{array}{l}\text { CFBE41o-, 16HBE14o-, } \\
\text { bronchial brushings }\end{array}$ & $A T F$ & [70] \\
\hline $\operatorname{miR}-31$ & $\downarrow$ & $\begin{array}{l}\text { PBECs, CFBE41o-, 16HBE14o-, } \\
\text { 9HTEo-, CFTE29o- }\end{array}$ & CTSS, IRF-1 & [73] \\
\hline $\begin{array}{c}\text { XIST } \\
\text { HOTAIR, MALAT, TLR8-AS1 }\end{array}$ & $\begin{array}{l}\uparrow \\
\downarrow\end{array}$ & bronchial brushings & $\overline{-}$ & [69] \\
\hline BGas & $\downarrow$ (inhibition) & $\begin{array}{l}\text { CFPAC cells, 1HAEo-, } \\
\text { CFBE41o-, 16HBE14o- }\end{array}$ & CFTR increased & [74] \\
\hline
\end{tabular}

HEK293 - human embryonic kidney cells, IB3-1 - primary human bronchial epithelial cells from CF patients, CFBEs

- cystic fibrosis bronchial epithelial cells, CFPAC - human Caucasian pancreatic adenocarcinoma, HBE - human bronchial epithelial cells, HAE - human airway epithelial cells, CFTE - human tracheal epithelial cells from cystic fibrosis, HTE - human tracheal epithelial cells, PBECs - primary bronchial epithelial cells. 
Another interesting strategy was reported recently by Zarilli et al. [75] who used peptide nucleic acids (PNAs) to prevent miRNA binding to the 3'UTR sequences of CFTR mRNA. The authors synthesized 7- and 13-base-long PNAs with the tetrapeptide Gly-SerP-SerP-Gly at their C-end that was complementary to the sequence recognized by miR-509-3p and blocked its binding to CFTR, thus enabling its expression. It seems an interesting approach to gene therapy for cystic fibrosis.

\section{Role of ncRNAs in Epithelial Function during Repair}

The airway epithelium acts as a physical barrier against antigens, microbes and viruses, due to the presence of tight junctions, adherens junctions, desmosomes, gap junctions, and hemidesmosomes [76]. Mucociliary clearance and the production of mucus allow the epithelium to trap foreign particles and transport it out of the respiratory system [77].

The epithelium may be damaged by respiratory viruses or microbes or by inhalation of airborne environmental irritants (tobacco smoke, pollutants) [78]. The injury itself causes an acute inflammatory response, resulting in recruitment of immune cells that release cytokines, chemokines, growth factors, and other factors that promote cell migration [79]. A defect in epithelial barrier function results in greater access by environmental allergens, pathogens, and toxicants, a primary cause underlying asthma pathogenesis [80], whereas in cystic fibrosis, ineffective clearing of pathogens leads to inflammation and pulmonary exacerbation [81]. Chronic inflammation of the airways results in aberrant $r$, decreasing lung function.

The MiRNA expression profile was altered during epithelial wound repair in an in vitro model of a bronchial epithelial cell line (16HBE14o-) with numerous miRNAs down- or up-regulated at different time points as compared to the pre-injury state [82]. Silencing Drosha and Dicer, enzymes crucial in miRNA biogenesis, significantly delayed epithelial repair in 16HBE14o- cells, thus confirming the important role of miRNAs during this process. Further research has revealed that miR-328 is involved in the airway epithelial repair and might regulate actin pathway [83].

\section{NcRNAs as Mediators of Epithelial Response to Environmental Stimuli}

\subsection{Bacterial and Viral Respiratory Infections}

Pseudomonas aeruginosa is the leading cause of chronic infections in cystic fibrosis, and infected bronchial epithelial cells from CF patients showed significant up- or down-regulation of 108 lncRNAs in comparison to the controls [84]. These lncRNAs were mostly responsible for regulation of the CTCF binding site and promoter sequence binding. Analysis of a specific signature in infected CF epithelium revealed 17 lncRNA transcripts; four of these were also differentially expressed in patients versus controls: MEG9, BLACAT1, RP11-47714.4 and RP11-1334A24.5. One of them, MEG9, down-regulated in infected epithelium, correlated with 251 protein coding genes involved in protein binding, regulation of cellular processes, and extracellular matrix, and were present during lung inflammation.

Among viral infections of the airways, the respiratory syncytial virus (RSV) is common human pathogen leading to severe respiratory illness that frequently require hospitalization in infants. A review by Rossi et al. [85] described several miRNAs that are regulated by RSV infection. Of most interest are miRNAs: let-7f, let-7i, miR-24, miR-26b, miR-27a, miR-221, miR-30b, miR-337, miR-339-5p, miR-453, miR-520a, miR-574, and miR-744. Several of these miRNAs were shown to activate or inhibit NF-kB and STAT signaling and cytokine production pathways. Microarray analysis of nasal mucosa identified several miRNAs with altered expression in acute RSV-positive infants (down-regulated miR-34b, miR-34c, miR-125b, miR-29c, mir125a, miR-429 and miR-27b and up-regulated miR-155, miR-31, miR-203a, miR-16 and let-7d) as compared to healthy infants [86]. The majority of these miRNAs regulate the immune system, suggesting they may be important in the immune response to viral infection.

Another class of small non-coding RNAs induced upon RSV infection in human airway epithelium are RNAs derived from transfer RNAs (tRNAs) and called tRNA-derived RNA fragments (tRFs) [87]. 
One of them, tRF5-GluCTC, was capable of trans-silencing target genes, suggesting that it controls viral replication by suppression of host defense genes. Moreover, a study by Zhou et al. has identified two novel tRFs that promote RSV replication: tRF5-GlyCCC and tRF5-LysCT [88].

Human metapneumovirus (hMPV) is another common virus that belongs to the same family as RSV (Paramyxoviridae) and also causes lower respiratory tract infections in infants and children [89]. hMPV infection of bronchial epithelium resulted in altered profile expression of 174 miRNAs. Functional studies revealed that let-7f inhibits hMPV replication and that the M2-2 hMPV protein blocking mitochondrial antiviral signaling inhibits the expression of miR-16 and miR-30a.

Rhinovirus (RV) infections are the most common cause of early-life respiratory infections and the most important cause of asthma exacerbations later in life [90]. Global microRNA profiles generated with NanoString microarrays performed in nasal airway secretions from RV-positive children identified miR-155 as a potential regulator of RV infection [91].

\subsection{Pollution}

Air pollution is associated with asthma development and exacerbations. MicroRNA expression profiling of human bronchial epithelial cells exposed to diesel exhaust particles showed altered expression of 197 miRNAs [92]. Network analysis of the putative targets of the most altered miRNAs has identified genes involved in inflammatory response and cancer. Bleck et al. discovered that miR-375 upregulates thymic stromal lymphoprotein (TSLP) mRNAs and proteins (which in cytokine-linking innate and Th2-adaptive immune disorders are overexpressed as a result of exposure to environmental pollutants) in human bronchial epithelial cells exposed to diesel exhaust particles and ambient particulate matter [93]. Investigators also confirmed that miR-375 downregulates the aryl hydrocarbon receptor (AhR), leading to activation of NF-KB pathway.

Another particle that alters respiratory immune responses is ozone. MiRNA expression profiling in sputum of subjects exposed to ozone inhalation revealed significantly up-regulated expression of 10 miRNAs: miR-132, miR-143, miR-145, miR-199a-3p, miR-199b-5p, miR-222, miR-223, miR-25, miR-424 and miR-582-5p [94]. Predicted targets of these miRNAs were predominantly genes associated with inflammation and immune response.

\subsection{Cigarette Smoke}

Rats exposed to environmental cigarette smoke (ECS) had significantly altered miRNA expression in the lungs [95]. Targets of the most remarkably down-regulated miRNAs (let-7, miR-10, miR-26, miR-30, miR-34, miR-99, miR-122, miR-123, miR-124, miR-125, miR-140, miR-145, miR-146, miR-191, miR-192, miR-219, miR-222, and miR-223) regulate proliferation, gene expression, stress response, apoptosis, and angiogenesis. Several of these miRNAs were also found to be significantly altered in a study comparing smokers to non-smokers [96]. Interestingly, electronic cigarettes were also found to affect miRNA expression profile in human bronchial epithelial cells: expression of 578 miRNAs was altered upon electronic cigarette liquid exposure, whereas 125 miRNAs were dysregulated after liquid vaporization [97].

The results of above mentioned ncRNAs studies are summarized in Table 3.

Table 3. A summary of ncRNA studies in airway cells exposed to different environmental stimuli.

\begin{tabular}{|c|c|c|c|c|c|c|}
\hline Class of ncRNA & Regulation & Tissue/Cell Type & Species & Condition/Treatment & Validated Target Genes & Ref. \\
\hline $\begin{array}{l}\text { lcRNAs: } M E G 9, \text { BLACAT1, } \\
\text { RP11-477I4.4, RP11-1334A24.5 }\end{array}$ & $\downarrow$ & $\begin{array}{l}\text { bronchial } \\
\text { epithelial cells }\end{array}$ & humans & $\begin{array}{l}\mathrm{CF}+\text { Pseudomonas } \\
\text { aeruginosa }\end{array}$ & - & [84] \\
\hline $\begin{array}{l}\text { miR-34b, miR-34c, miR-125b, miR-29c, } \\
\text { mir125a, miR-429 miR-27b }\end{array}$ & $\uparrow$ & \multirow{2}{*}{$\begin{array}{l}\text { nasal epithelium } \\
\text { brushings }\end{array}$} & \multirow{2}{*}{ humans } & \multirow{2}{*}{ RSV } & - & \multirow{2}{*}{ [86] } \\
\hline $\begin{array}{l}\mathrm{miR}-155, \mathrm{miR}-31, \mathrm{miR}-203 \mathrm{a}, \mathrm{miR}-16 \\
\text { and let-7d }\end{array}$ & $\downarrow$ & & & & - & \\
\hline
\end{tabular}


Table 3. Cont.

\begin{tabular}{|c|c|c|c|c|c|c|}
\hline Class of ncRNA & Regulation & Tissue/Cell Type & Species & Condition/Treatment & Validated Target Genes & Ref. \\
\hline tRF5-GlyCCC, tRF5-LysCT & $\uparrow$ & $\begin{array}{l}\text { lung carcinoma } \\
\text { cell line (A549) }\end{array}$ & humans & RSV & - & [88] \\
\hline let-7f & $\uparrow$ & $\begin{array}{l}\text { lung carcinoma } \\
\text { cell line (A549) }\end{array}$ & humans & hMPV & - & [89] \\
\hline miR-155 & $\uparrow$ & $\begin{array}{l}\text { nasal airway } \\
\text { secretions }\end{array}$ & humans & RV & - & [91] \\
\hline $\begin{array}{l}\text { miR-31-3p, miR-26b, miR-96, miR-27a, } \\
\text { miR-135b, miR-374a }\end{array}$ & $\downarrow$ & $\begin{array}{l}\text { bronchial } \\
\text { epithelial cells }\end{array}$ & humans & DEP & - & [92] \\
\hline miR-375 & $\uparrow$ & $\begin{array}{c}\text { bronchial } \\
\text { epithelial cells }\end{array}$ & humans & DEP, APM & $T S L P, A h R$ & [93] \\
\hline $\begin{array}{l}\text { miR-132, miR-143, miR-145, miR-199a-3p, } \\
\text { miR-199b-5p, miR-222, miR-223, miR-25, } \\
\text { miR-424 and miR-582-5p }\end{array}$ & $\uparrow$ & sputum & humans & Ozone & - & [94] \\
\hline $\begin{array}{l}\text { hsa-miR-337, hsa-miR-18a-3p, hsa-miR-189, } \\
\text { hsa-miR-365, hsa-miR-181d }\end{array}$ & $\uparrow$ & \multirow{3}{*}{$\begin{array}{l}\text { bronchial } \\
\text { epithelial cells }\end{array}$} & \multirow{3}{*}{ humans } & \multirow{3}{*}{ ECS } & - & \multirow{3}{*}{96} \\
\hline $\begin{array}{c}\text { hsa-miR-10b, hsa-miR-150, hsa-miR-338, } \\
\text { hsa-miR-362, hsa-miR-17-3p, hsa-miR-15a, } \\
\text { hsa-miR-652, hsa-miR-106b, hsa-miR-19b, } \\
\text { hsa-miR-106a, hsa-miR-128a, } \\
\text { hsa-miR-30a-3p, hsa-miR-128b, } \\
\text { hsa-miR-130a, hsa-miR-500, hsa-miR-363, } \\
\text { hsa-miR-199b, hsa-miR-223, hsa-miR-625, } \\
\text { hsa-miR-99a, hsa-miR-125b, hsa-miR-146a }\end{array}$ & $\downarrow$ & & & & - & \\
\hline hsa-miR-218 & $\downarrow$ & & & & $\begin{array}{l}\text { MAFG, NAC-1, } \\
\text { ECOP, LASP1 }\end{array}$ & \\
\hline
\end{tabular}

RSV: respiratory syncytial virus; hMPV: human metapneumovirus; RV: rhinovirus, DEP: diesel exhaust particles;

APM: ambient particulate matter; ECS: environmental cigarette smoke; CF: cystic fibrosis.

\section{Perspectives}

Non-coding RNAs have been extensively studied in many diseases, including respiratory illnesses. Identification of ncRNAs and their role in RNA transcription allows for better understanding about the pathogenesis of respiratory diseases. The development of targeted therapy using inhibitors or synthetic ncRNAs could be a breakthrough in the treatment of these diseases. However, taking into account the complexity of ncRNA regulation, it remains a challenge to use them as biomarkers or therapeutic targets.

Acknowledgments: The study was supported by National Science Centre, Poland, grant No. 2016/22/E/NZ5/00383.

Author Contributions: Beata Narożna, Wojciech Langwiński, and Aleksandra Szczepankiewicz participated in conception and study design, performed the literature search and interpretation, drafted the paper, and revised the final version of the manuscript.

Conflicts of Interest: The authors declare no conflict of interest. The founding sponsors had no role in the design of the study; in the collection, analyses, or interpretation of data; in the writing of the manuscript, and in the decision to publish the results.

\section{References}

1. Xie, N.; Liu, G. ncRNA-regulated immune response and its role in inflammatory lung diseases. Am. J. Physiol. Lung Cell. Mo.l Physiol. 2015, 309, 1076-1087. [CrossRef] [PubMed]

2. Clark, M.B.; Choudhary, A.; Smith, M.A.; Taft, R.J.; Mattick, J.S. The dark matter rises: the expanding world of regulatory RNAs. Essays Biochem. 2013, 54,1-16. [CrossRef] [PubMed]

3. Mercer, T.R.; Dinger, M.E.; Mattick, J.S. Long non-coding rnas: Insights into functions. Nat. Rev. Genet. 2009, 10, 155-159. [CrossRef] [PubMed] 
4. Kim, V.N. MicroRNA biogenesis: Coordinated cropping and dicing. Nat. Rev. Mol. Cell Biol. 2005, 6, 376-385. [CrossRef] [PubMed]

5. Friedman, R.C.; Farh, K.K.; Burge, C.B.; Bartel, D.P. Most mammalian mRNAs are conserved targets of microRNAs. Genome Res. 2009, 19, 92-105. [CrossRef] [PubMed]

6. He, L.; Hannon, G.J. MicroRNAs: Small RNAs with a big role in gene regulation. Nat. Rev. Genet. 2004, 5, 522-531. [CrossRef] [PubMed]

7. Iwasaki, Y.W.; Siomi, M.C.; Siomi, H. PIWI-interacting RNA: Its biogenesis and functions. Annu. Rev. Biochem. 2015, 84, 405-433. [CrossRef] [PubMed]

8. Zhong, F.; Zhou, N.; Wu, K.; Guo, Y.; Tan, W.; Zhang, H.; Zhang, X.; Geng, G.; Pan, T.; Luo, H.; et al. A SnoRNA-derived piRNA interacts with human interleukin-4 pre-mRNA and induces its decay in nuclear exosomes. Nucleic Acids Res. 2015, 43, 10474-10491. [PubMed]

9. Quinn, J.J.; Chang, H.Y. Unique features of long non-coding RNA biogenesis and function. Nat. Rev. Genet. 2016, 17, 47-62. [CrossRef] [PubMed]

10. Ponting, C.P.; Oliver, P.L.; Reik, W. Evolution and functions of long noncoding RNAs. Cell 2009, 136, 629-641. [CrossRef] [PubMed]

11. Gutschner, T.; Diederichs, S. The hallmarks of cancer: a long non-coding RNA point of view. RNA Biol. 2012, 9, 703-719. [CrossRef] [PubMed]

12. Rinn, J.L.; Chang, H.Y. Genome regulation by long noncoding RNAs. Annu. Rev. Biochem. 2012, 81, $145-166$. [CrossRef] [PubMed]

13. Gallach, S.; Calabuig-Farinas, S.; Jantus-Lewintre, E.; Camps, C. MicroRNAs: Promising new antiangiogenic targets in cancer. BioMed. Res. Int. 2014. [CrossRef] [PubMed]

14. Kent, O.A.; Mendell, J.T. A small piece in the cancer puzzle: microRNAs as tumor suppressors and oncogenes. Oncogene 2006, 25, 6188-6196. [CrossRef] [PubMed]

15. Benson, M.; Svensson, P.A.; Carlsson, B.; Jernas, M.; Reinholdt, J.; Cardell, L.O.; Carlsson, L. DNA microarrays to study gene expression in allergic airways. Clin. Exp. Allergy 2002, 32, 301-308. [CrossRef] [PubMed]

16. Gladkevich, A.; Nelemans, S.A.; Kauffman, H.F.; Korf, J. Microarray profiling of lymphocytes in internal diseases with an altered immune response: Potential and methodology. Mediators Inflamm. 2005, 2005, 317-330. [CrossRef] [PubMed]

17. Ono, S.J.; Nakamura, T.; Ohbayashi, M.; Dawson, M.; Ikeda, Y.; Nugent, A.K.; Toda, M.; Jay, G. Expression profiling: Opportunities and pitfalls and impact on the study and management of allergic diseases. J. Allergy Clin. Immunol. 2003, 112, 1050-1056. [CrossRef] [PubMed]

18. Liu, F.; Qin, H.B.; Xu, B.; Zhou, H.; Zhao, D.Y. Profiling of miRNAs in pediatric asthma: Upregulation of miRNA-221 and miRNA-485-3p. Mol. Med. Rep. 2012, 6, 1178-1182. [CrossRef] [PubMed]

19. Zhou, Y.; Yang, Q.; Xu, H.; Zhang, J.; Deng, H.; Gao, H.; Yang, J.; Zhao, D.; Liu, F. miRNA-221-3p enhances the secretion of interleukin-4 in mast cells through the phosphatase and tensin homolog/p38/nuclear factor-kappab pathway. PLOS ONE 2016, 11. [CrossRef] [PubMed]

20. Qin, H.B.; Xu, B.; Mei, J.J.; Li, D.; Liu, J.J.; Zhao, D.Y.; Liu, F. Inhibition of miRNA-221 suppresses the airway inflammation in asthma. Inflammation 2012, 35, 1595-1599. [CrossRef] [PubMed]

21. Mayoral, R.J.; Deho, L.; Rusca, N.; Bartonicek, N.; Saini, H.K.; Enright, A.J.; Monticelli, S. MiR-221 influences effector functions and actin cytoskeleton in mast cells. PLoS ONE 2011, 6. [CrossRef] [PubMed]

22. Perry, M.M.; Baker, J.E.; Gibeon, D.S.; Adcock, I.M.; Chung, K.F. Airway smooth muscle hyperproliferation is regulated by microRNA-221 in severe asthma. Am. J. Respir. Cell Mol. Biol. 2014, 50, 7-17. [CrossRef] [PubMed]

23. Pinkerton, M.; Chinchilli, V.; Banta, E.; Craig, T.; August, A.; Bascom, R.; Cantorna, M.; Harvill, E.; Ishmael, F.T. Differential expression of microRNAs in exhaled breath condensates of patients with asthma, patients with chronic obstructive pulmonary disease, and healthy adults. J. Allergy Clin. Immunol. 2013, 132, 217-219. [CrossRef] [PubMed]

24. Levanen, B.; Bhakta, N.R.; Torregrosa Paredes, P.; Barbeau, R.; Hiltbrunner, S.; Pollack, J.L.; Skold, C.M.; Svartengren, M.; Grunewald, J.; Gabrielsson, S.; et al. Altered microRNA profiles in bronchoalveolar lavage fluid exosomes in asthmatic patients. J. Allergy Clin. Immunol. 2013, 131, 894-903. [CrossRef] [PubMed]

25. Suojalehto, H.; Lindstrom, I.; Majuri, M.L.; Mitts, C.; Karjalainen, J.; Wolff, H.; Alenius, H. Altered microRNA expression of nasal mucosa in long-term asthma and allergic rhinitis. Int. Arch. Allergy Immunol. 2014, 163, 168-178. [CrossRef] [PubMed] 
26. Sawant, D.V.; Yao, W.; Wright, Z.; Sawyers, C.; Tepper, R.S.; Gupta, S.K.; Kaplan, M.H.; Dent, A.L. Serum microRNA-21 as a biomarker for allergic inflammatory disease in children. Microrna 2015, 4, 36-40. [CrossRef] [PubMed]

27. Lu, T.X.; Munitz, A.; Rothenberg, M.E. MicroRNA-21 is up-regulated in allergic airway inflammation and regulates il-12p35 expression. J. Immunol. 2009, 182, 4994-5002. [CrossRef] [PubMed]

28. Lu, T.X.; Hartner, J.; Lim, E.J.; Fabry, V.; Mingler, M.K.; Cole, E.T.; Orkin, S.H.; Aronow, B.J.; Rothenberg, M.E. MicroRNA-21 limits in vivo immune response-mediated activation of the IL-12/ifn-gamma pathway, Th1 polarization, and the severity of delayed-type hypersensitivity. J. Immunol. 2011, 187, 3362-3373. [CrossRef] [PubMed]

29. Wu, X.B.; Wang, M.Y.; Zhu, H.Y.; Tang, S.Q.; You, Y.D.; Xie, Y.Q. Overexpression of microRNA-21 and microRNA-126 in the patients of bronchial asthma. Int. J. Clin. Exp. Med. 2014, 7, 1307-1312. [PubMed]

30. Collison, A.; Herbert, C.; Siegle, J.S.; Mattes, J.; Foster, P.S.; Kumar, R.K. Altered expression of microRNA in the airway wall in chronic asthma: miR-126 as a potential therapeutic target. BMC Pulm. Med. 2011, 11, 29. [CrossRef] [PubMed]

31. Wang, J.W.; Li, K.; Hellermann, G.; Lockey, R.F.; Mohapatra, S.; Mohapatra, S. Regulating the regulators: microRNA and asthma. World Allergy Organ. J. 2011, 4, 94-103. [CrossRef] [PubMed]

32. Taganov, K.D.; Boldin, M.P.; Chang, K.J.; Baltimore, D. NF-kappaB-dependent induction of microRNA miR-146, an inhibitor targeted to signaling proteins of innate immune responses. Proc. Natl. Acad. Sci. USA 2006, 103, 12481-12486. [CrossRef] [PubMed]

33. Tsitsiou, E.; Williams, A.E.; Moschos, S.A.; Patel, K.; Rossios, C.; Jiang, X.; Adams, O.D.; Macedo, P.; Booton, R.; Gibeon, D.; et al. Transcriptome analysis shows activation of circulating CD8+ T cells in patients with severe asthma. J. Allergy Clin. Immunol. 2012, 129, 95-103. [CrossRef] [PubMed]

34. Yamamoto, M.; Singh, A.; Ruan, J.; Gauvreau, G.M.; O’Byrne, P.M.; Carlsten, C.R.; FitzGerald, J.M.; Boulet, L.P.; Tebbutt, S.J. Decreased miR-192 expression in peripheral blood of asthmatic individuals undergoing an allergen inhalation challenge. BMC genomics 2012, 13, 655. [CrossRef] [PubMed]

35. Lacedonia, D.; Palladino, G.P.; Foschino-Barbaro, M.P.; Scioscia, G.; Carpagnano, G.E. Expression profiling of miRNA-145 and miRNA-338 in serum and sputum of patients with copd, asthma, and asthma-copd overlap syndrome phenotype. Int. J. Chron. Obstruct. Pulmon. Dis. 2017, 12, 1811-1817. [CrossRef] [PubMed]

36. Maes, T.; Cobos, F.A.; Schleich, F.; Sorbello, V.; Henket, M.; De Preter, K.; Bracke, K.R.; Conickx, G.; Mesnil, C.; Vandesompele, J.; et al. Asthma inflammatory phenotypes show differential microRNA expression in sputum. J. Allergy Clin. Immunol. 2016, 137, 1433-1446. [CrossRef] [PubMed]

37. Malmhall, C.; Johansson, K.; Winkler, C.; Alawieh, S.; Ekerljung, L.; Radinger, M. Altered miR-155 expression in allergic asthmatic airways. Scand. J. Immunol. 2017, 85, 300-307. [CrossRef] [PubMed]

38. Martinez-Nunez, R.T.; Bondanese, V.P.; Louafi, F.; Francisco-Garcia, A.S.; Rupani, H.; Bedke, N.; Holgate, S.; Howarth, P.H.; Davies, D.E.; Sanchez-Elsner, T. A microRNA network dysregulated in asthma controls IL-6 production in bronchial epithelial cells. PLoS ONE 2014, 9. [CrossRef] [PubMed]

39. Rodriguez, A.; Vigorito, E.; Clare, S.; Warren, M.V.; Couttet, P.; Soond, D.R.; van Dongen, S.; Grocock, R.J.; Das, P.P.; Miska, E.A.; et al. Requirement of bic/microRNA-155 for normal immune function. Science 2007, 316, 608-611. [CrossRef] [PubMed]

40. Haj-Salem, I.; Fakhfakh, R.; Berube, J.C.; Jacques, E.; Plante, S.; Simard, M.J.; Bosse, Y.; Chakir, J. MicroRNA-19a enhances proliferation of bronchial epithelial cells by targeting TGF $\beta$ R2 gene in severe asthma. Allergy 2015, 70, 212-219. [CrossRef] [PubMed]

41. Jardim, M.J.; Dailey, L.; Silbajoris, R.; Diaz-Sanchez, D. Distinct microRNA expression in human airway cells of asthmatic donors identifies a novel asthma-associated gene. Am. J. Respir. Cell Mol. Biol. 2012, 47, 536-542. [CrossRef] [PubMed]

42. Marcet, B.; Chevalier, B.; Luxardi, G.; Coraux, C.; Zaragosi, L.E.; Cibois, M.; Robbe-Sermesant, K.; Jolly, T.; Cardinaud, B.; Moreilhon, C.; et al. Control of vertebrate multiciliogenesis by miR-449 through direct repression of the delta/notch pathway. Nat. Cell Biol. 2011, 13, 693-699. [CrossRef] [PubMed]

43. Bartel, S.; Schulz, N.; Alessandrini, F.; Schamberger, A.C.; Pagel, P.; Theis, F.J.; Milger, K.; Noessner, E.; Stick, S.M.; Kicic, A.; et al. Pulmonary microRNA profiles identify involvement of Creb1 and Sec1413 in bronchial epithelial changes in allergic asthma. Sci. Rep. 2017, 7, 46026. [CrossRef] [PubMed] 
44. Austin, P.J.; Tsitsiou, E.; Boardman, C.; Jones, S.W.; Lindsay, M.A.; Adcock, I.M.; Chung, K.F.; Perry, M.M. Transcriptional profiling identifies the long noncoding RNA plasmacytoma variant translocation (PVT1) as a novel regulator of the asthmatic phenotype in human airway smooth muscle. J. Allergy Clin. Immunol. 2017, 139, 780-789. [CrossRef] [PubMed]

45. Zhang, X.Y.; Zhang, L.X.; Tian, C.J.; Tang, X.Y.; Zhao, L.M.; Guo, Y.L.; Cheng, D.J.; Chen, X.L.; Ma, L.J.; Chen, Z.C. LncRNAs BCYRN1 promoted the proliferation and migration of rat airway smooth muscle cells in asthma via upregulating the expression of transient receptor potential 1. Am. J. Transl. Res. 2016, 8, 3409-3418. [PubMed]

46. Polikepahad, S.; Knight, J.M.; Naghavi, A.O.; Oplt, T.; Creighton, C.J.; Shaw, C.; Benham, A.L.; Kim, J.; Soibam, B.; Harris, R.A.; et al. Proinflammatory role for let-7 microRNAs in experimental asthma. J. Biol. Chem. 2010, 285, 30139-30149. [CrossRef] [PubMed]

47. Comer, B.S.; Camoretti-Mercado, B.; Kogut, P.C.; Halayko, A.J.; Solway, J.; Gerthoffer, W.T. MicroRNA-146a and microRNA-146b expression and anti-inflammatory function in human airway smooth muscle. Am. J. Physiol. Lung Cell Mol. Physiol. 2014, 307, 727-734. [CrossRef] [PubMed]

48. Jazdzewski, K.; Murray, E.L.; Franssila, K.; Jarzab, B.; Schoenberg, D.R.; de la Chapelle, A. Common SNP in pre-miR-146a decreases mature miR expression and predisposes to papillary thyroid carcinoma. Proc. Natl. Acad. Sci. USA 2008, 105, 7269-7274. [CrossRef] [PubMed]

49. Jimenez-Morales, S.; Gamboa-Becerra, R.; Baca, V.; Del Rio-Navarro, B.E.; Lopez-Ley, D.Y.; Velazquez-Cruz, R.; Saldana-Alvarez, Y.; Salas-Martinez, G.; Orozco, L. MiR-146a polymorphism is associated with asthma but not with systemic lupus erythematosus and juvenile rheumatoid arthritis in Mexican patients. Tissue Antigens 2012, 80, 317-321. [CrossRef] [PubMed]

50. Toraih, E.A.; Hussein, M.H.; Al Ageeli, E.; Riad, E.; AbdAllah, N.B.; Helal, G.M.; Fawzy, M.S. Structure and functional impact of seed region variant in MIR-499 gene family in bronchial asthma. Respir. Res. 2017, 18, 169. [CrossRef] [PubMed]

51. Trinh, H.K.T.; Pham, D.L.; Kim, S.C.; Kim, R.Y.; Park, H.S.; Kim, S.H. Association of the miR-196a2, miR-146a, and miR-499 polymorphisms with asthma phenotypes in a Korean population. Mol. Diagn. Ther. 2017. [CrossRef] [PubMed]

52. Kho, A.T.; Sharma, S.; Davis, J.S.; Spina, J.; Howard, D.; McEnroy, K.; Moore, K.; Sylvia, J.; Qiu, W.; Weiss, S.T.; et al. Circulating MicroRNAs: Association with lung function in asthma. PLoS ONE 2016, 11. [CrossRef] [PubMed]

53. Gon, Y.; Maruoka, S.; Inoue, T.; Kuroda, K.; Yamagishi, K.; Kozu, Y.; Shikano, S.; Soda, K.; Lotvall, J.; Hashimoto, S. Selective release of miRNAs via extracellular vesicles is associated with house dust mite allergen-induced airway inflammation. Clin. Exp. Allergy 2017. [CrossRef] [PubMed]

54. Solberg, O.D.; Ostrin, E.J.; Love, M.I.; Peng, J.C.; Bhakta, N.R.; Hou, L.; Nguyen, C.; Solon, M.; Barczak, A.J.; Zlock, L.T.; et al. Airway epithelial miRNA expression is altered in asthma. Am. J. Respir. Crit. Care Med. 2012, 186, 965-974. [CrossRef] [PubMed]

55. Williams, A.E.; Larner-Svensson, H.; Perry, M.M.; Campbell, G.A.; Herrick, S.E.; Adcock, I.M.; Erjefalt, J.S.; Chung, K.F.; Lindsay, M.A. MicroRNA expression profiling in mild asthmatic human airways and effect of corticosteroid therapy. PLoS ONE 2009, 4. [CrossRef] [PubMed]

56. Sweeney, M.; McDaniel, S.S.; Platoshyn, O.; Zhang, S.; Yu, Y.; Lapp, B.R.; Zhao, Y.; Thistlethwaite, P.A.; Yuan, J.X. Role of capacitative Ca2+ entry in bronchial contraction and remodeling. J. Appl. Physiol. (1985) 2002, 92, 1594-1602. [CrossRef] [PubMed]

57. Britto, M.T.; Kotagal, U.R.; Hornung, R.W.; Atherton, H.D.; Tsevat, J.; Wilmott, R.W. Impact of recent pulmonary exacerbations on quality of life in patients with cystic fibrosis. Chest 2002, 121, 64-72. [CrossRef] [PubMed]

58. Megiorni, F.; Cialfi, S.; Cimino, G.; De Biase, R.V.; Dominici, C.; Quattrucci, S.; Pizzuti, A. Elevated levels of miR-145 correlate with SMAD3 down-regulation in cystic fibrosis patients. J. Cyst. Fibros. 2013, 12, 797-802. [CrossRef] [PubMed]

59. Megiorni, F.; Cialfi, S.; Dominici, C.; Quattrucci, S.; Pizzuti, A. Synergistic post-transcriptional regulation of the cystic fibrosis transmembrane conductance regulator (CFTR) by miR-101 and miR-494 specific binding. PLoS ONE 2011, 6. [CrossRef] [PubMed]

60. Gillen, A.E.; Gosalia, N.; Leir, S.H.; Harris, A. MicroRNA regulation of expression of the cystic fibrosis transmembrane conductance regulator gene. Biochem. J. 2011, 438, 25-32. [CrossRef] [PubMed] 
61. Oglesby, I.K.; Chotirmall, S.H.; McElvaney, N.G.; Greene, C.M. Regulation of cystic fibrosis transmembrane conductance regulator by microRNA-145, -223 , and -494 is altered in $\triangle$ F508 cystic fibrosis airway epithelium. J. Immunol. 2013, 190, 3354-3362. [CrossRef] [PubMed]

62. Ramachandran, S.; Karp, P.H.; Osterhaus, S.R.; Jiang, P.; Wohlford-Lenane, C.; Lennox, K.A.; Jacobi, A.M.; Praekh, K.; Rose, S.D.; Behlke, M.A.; et al. Post-transcriptional regulation of cystic fibrosis transmembrane conductance regulator expression and function by microRNAs. Am. J. Respir. Cell Mol. Biol. 2013, 49, 544-551. [CrossRef] [PubMed]

63. Ramachandran, S.; Karp, P.H.; Jiang, P.; Ostedgaard, L.S.; Walz, A.E.; Fisher, J.T.; Keshavjee, S.; Lennox, K.A.; Jacobi, A.M.; Rose, S.D.; et al. A microRNA network regulates expression and biosynthesis of wild-type and DeltaF508 mutant cystic fibrosis transmembrane conductance regulator. Proc. Natl. Acad. Sci. USA 2012, 109, 13362-13367. [CrossRef] [PubMed]

64. Amato, F.; Seia, M.; Giordano, S.; Elce, A.; Zarrilli, F.; Castaldo, G.; Tomaiuolo, R. Gene mutation in microRNA target sites of CFTR gene: A novel pathogenetic mechanism in cystic fibrosis? PLoS ONE 2013, 8. [CrossRef] [PubMed]

65. Kumar, P.; Bhattacharyya, S.; Peters, K.W.; Glover, M.L.; Sen, A.; Cox, R.T.; Kundu, S.; Caohuy, H.; Frizzell, R.A.; Pollard, H.B.; et al. miR-16 rescues F508del-CFTR function in native cystic fibrosis epithelial cells. Gene Ther. 2015, 22, 908-916. [CrossRef] [PubMed]

66. Endale Ahanda, M.L.; Bienvenu, T.; Sermet-Gaudelus, I.; Mazzolini, L.; Edelman, A.; Zoorob, R.; Davezac, N. The hsa-miR-125a/hsa-let-7e/hsa-miR-99b cluster is potentially implicated in cystic fibrosis pathogenesis. J. Cyst. Fibros. 2015, 14, 571-579. [CrossRef] [PubMed]

67. Sonneville, F.; Ruffin, M.; Coraux, C.; Rousselet, N.; Le Rouzic, P.; Blouquit-Laye, S.; Corvol, H.; Tabary, O. MicroRNA-9 downregulates the ANO1 chloride channel and contributes to cystic fibrosis lung pathology. Nat. Commun. 2017, 8. [CrossRef] [PubMed]

68. Rebane, A.; Akdis, C.A. MicroRNAs: Essential players in the regulation of inflammation. J. Allergy Clin. Immunol. 2013, 132, 15-26. [CrossRef] [PubMed]

69. McKiernan, P.J.; Molloy, K.; Cryan, S.A.; McElvaney, N.G.; Greene, C.M. Long noncoding RNA are aberrantly expressed in vivo in the cystic fibrosis bronchial epithelium. Int. J. Biochem. Cell Biol. 2014, 52, 184-191. [CrossRef] [PubMed]

70. Oglesby, I.K.; Agrawal, R.; Mall, M.A.; McElvaney, N.G.; Greene, C.M. miRNA-221 is elevated in cystic fibrosis airway epithelial cells and regulates expression of ATF6. Mol. Cell Pediatr. 2015, 2. [CrossRef] [PubMed]

71. Bhattacharyya, S.; Balakathiresan, N.S.; Dalgard, C.; Gutti, U.; Armistead, D.; Jozwik, C.; Srivastava, M.; Pollard, H.B.; Biswas, R. Elevated miR-155 promotes inflammation in cystic fibrosis by driving hyperexpression of interleukin-8. J. Biol. Chem. 2011, 286, 11604-11615. [CrossRef] [PubMed]

72. Oglesby, I.K.; Bray, I.M.; Chotirmall, S.H.; Stallings, R.L.; O'Neill, S.J.; McElvaney, N.G.; Greene, C.M. miR-126 is downregulated in cystic fibrosis airway epithelial cells and regulates TOM1 expression. J. Immunol. 2010, 184, 1702-1709. [CrossRef] [PubMed]

73. Weldon, S.; McNally, P.; McAuley, D.F.; Oglesby, I.K.; Wohlford-Lenane, C.L.; Bartlett, J.A.; Scott, C.J.; McElvaney, N.G.; Greene, C.M.; McCray, P.B., Jr.; et al. miR-31 dysregulation in cystic fibrosis airways contributes to increased pulmonary cathepsin S production. Am. J. Respir. Crit. Care Med. 2014, 190, 165-174. [CrossRef] [PubMed]

74. Saayman, S.M.; Ackley, A.; Burdach, J.; Clemson, M.; Gruenert, D.C.; Tachikawa, K.; Chivukula, P.; Weinberg, M.S.; Morris, K.V. Long non-coding RNA BGas regulates the cystic fibrosis transmembrane conductance regulator. Mol. Ther. 2016, 24, 1351-1357. [CrossRef] [PubMed]

75. Zarrilli, F.; Amato, F.; Morgillo, C.M.; Pinto, B.; Santarpia, G.; Borbone, N.; D'Errico, S.; Catalanotti, B.; Piccialli, G.; Castaldo, G.; et al. Peptide nucleic acids as miRNA target protectors for the treatment of cystic fibrosis. Molecules 2017, 22. [CrossRef] [PubMed]

76. Holgate, S.T. The airway epithelium is central to the pathogenesis of asthma. Allergol. Int. 2008, 57, 1-10. [CrossRef] [PubMed]

77. Ganesan, S.; Comstock, A.T.; Sajjan, U.S. Barrier function of airway tract epithelium. Tissue Barriers 2013, 1. [CrossRef] [PubMed]

78. Rogers, D.F. The airway goblet cell. Int. J. Biochem. Cell Biol. 2003, 35, 1-6. [CrossRef] 
79. Crosby, L.M.; Waters, C.M. Epithelial repair mechanisms in the lung. Am. J. Physiol. Lung Cell. Mol. Physiol. 2010, 298. [CrossRef] [PubMed]

80. Holgate, S.T.; Roberts, G.; Arshad, H.S.; Howarth, P.H.; Davies, D.E. The role of the airway epithelium and its interaction with environmental factors in asthma pathogenesis. Proc. Am. Thorac. Soc. 2009, 6, 655-659. [CrossRef] [PubMed]

81. Cantin, A.M.; Hartl, D.; Konstan, M.W.; Chmiel, J.F. Inflammation in cystic fibrosis lung disease: Pathogenesis and therapy. J. Cyst. Fibros. 2015, 14, 419-430. [CrossRef] [PubMed]

82. Szczepankiewicz, A.; Lackie, P.M.; Holloway, J.W. Altered microRNA expression profile during epithelial wound repair in bronchial epithelial cells. BMC Pulm. Med. 2013, 13. [CrossRef] [PubMed]

83. Narozna, B.; Langwinski, W.; Jackson, C.; Lackie, P.; Holloway, J.W.; Szczepankiewicz, A. MicroRNA-328 is involved in wound repair process in human bronchial epithelial cells. Respir. Physiol. Neurobiol. 2017, 242, 59-65. [CrossRef] [PubMed]

84. Balloy, V.; Koshy, R.; Perra, L.; Corvol, H.; Chignard, M.; Guillot, L.; Scaria, V. Bronchial epithelial cells from cystic fibrosis patients express a specific long non-coding RNA signature upon pseudomonas aeruginosa infection. Front. Cell. Infect. Microbiol. 2017, 7. [CrossRef] [PubMed]

85. Rossi, G.A.; Silvestri, M.; Colin, A.A. Respiratory syncytial virus infection of airway cells: Role of microRNAs. Pediatr. Pulmonol. 2015, 50, 727-732. [CrossRef] [PubMed]

86. Inchley, C.S.; Sonerud, T.; Fjaerli, H.O.; Nakstad, B. Nasal mucosal microRNA expression in children with respiratory syncytial virus infection. BMC infect. Dis. 2015, 15. [CrossRef] [PubMed]

87. Wang, Q.; Lee, I.; Ren, J.; Ajay, S.S.; Lee, Y.S.; Bao, X. Identification and functional characterization of tRNA-derived RNA fragments (tRFs) in respiratory syncytial virus infection. Mol. Ther. 2013, 21, 368-379. [CrossRef] [PubMed]

88. Zhou, J.; Liu, S.; Chen, Y.; Fu, Y.; Silver, A.J.; Hill, M.S.; Lee, I.; Lee, Y.S.; Bao, X. Identification of two novel functional tRNA-derived fragments induced in response to respiratory syncytial virus infection. J. Gen. Virol. 2017, 98, 1600-1610. [CrossRef] [PubMed]

89. Deng, J.; Ptashkin, R.N.; Wang, Q.; Liu, G.; Zhang, G.; Lee, I.; Lee, Y.S.; Bao, X. Human metapneumovirus infection induces significant changes in small noncoding RNA expression in airway epithelial cells. Mol. Ther. Nucleic Acids 2014, 3. [CrossRef] [PubMed]

90. Song, D.J. Rhinovirus and childhood asthma: An update. Korean J. Pediatr. 2016, 59, 432-439. [CrossRef] [PubMed]

91. Gutierrez, M.J.; Gomez, J.L.; Perez, G.F.; Pancham, K.; Val, S.; Pillai, D.K.; Giri, M.; Ferrante, S.; Freishtat, R.; Rose, M.C.; et al. Airway secretory microRNAome changes during rhinovirus infection in early childhood. PLOS ONE 2016, 11. [CrossRef] [PubMed]

92. Jardim, M.J.; Fry, R.C.; Jaspers, I.; Dailey, L.; Diaz-Sanchez, D. Disruption of microRNA expression in human airway cells by diesel exhaust particles is linked to tumorigenesis-associated pathways. Environ. Health Perspect. 2009, 117, 1745-1751. [CrossRef] [PubMed]

93. Bleck, B.; Grunig, G.; Chiu, A.; Liu, M.; Gordon, T.; Kazeros, A.; Reibman, J. MicroRNA-375 regulation of thymic stromal lymphopoietin by diesel exhaust particles and ambient particulate matter in human bronchial epithelial cells. J. Immunol. 2013, 190, 3757-3763. [CrossRef] [PubMed]

94. Fry, R.C.; Rager, J.E.; Bauer, R.; Sebastian, E.; Peden, D.B.; Jaspers, I.; Alexis, N.E. Air toxics and epigenetic effects: Ozone altered microRNAs in the sputum of human subjects. Am. J. Physiol. Lung Cell. Mol. Physiol. 2014, 306. [CrossRef] [PubMed]

95. Izzotti, A.; Calin, G.A.; Arrigo, P.; Steele, V.E.; Croce, C.M.; De Flora, S. Downregulation of microRNA expression in the lungs of rats exposed to cigarette smoke. FASEB J 2009, 23, 806-812. [CrossRef] [PubMed]

96. Schembri, F.; Sridhar, S.; Perdomo, C.; Gustafson, A.M.; Zhang, X.; Ergun, A.; Lu, J.; Liu, G.; Zhang, X.; Bowers, J.; et al. MicroRNAs as modulators of smoking-induced gene expression changes in human airway epithelium. Proc. Natl. Acad. Sci. USA 2009, 106, 2319-2324. [CrossRef] [PubMed]

97. Solleti, S.K.; Bhattacharya, S.; Ahmad, A.; Wang, Q.; Mereness, J.; Rangasamy, T.; Mariani, T.J. MicroRNA expression profiling defines the impact of electronic cigarettes on human airway epithelial cells. Sci. Rep. 2017, 7. [CrossRef] [PubMed]

(C) 2017 by the authors. Licensee MDPI, Basel, Switzerland. This article is an open access article distributed under the terms and conditions of the Creative Commons Attribution (CC BY) license (http://creativecommons.org/licenses/by/4.0/). 